JRPB, Vol. 7, No. 2, September 2019, Hal. 249-257

DOI: $10.29 .303 / \mathrm{jrpb} . \mathrm{v} / 7 \mathrm{i} 2.139$

ISSN 2301-8119, e-ISSN 2443-1354

Tersedia online di http://jrpb.unram.ac.id/

\title{
PREDIKSI HASIL PANEN PADI MENGGUNAKAN PESAWAT TANPA AWAK
}

\author{
Prediction of Rice Harvest Using Unmanned Aircraft
}

\author{
Abdul Holik ${ }^{1, *}$, Riza Rahimi Bachtiar ${ }^{2}$ \\ ${ }^{1,2}$ Program Studi Agribisnis Politeknik Negeri Banyuwangi \\ Jl. Raya Jember Km 13 Labanasem Kabat Banyuwangi Jawa Timur 68461 Indonesia \\ Email": abdulholik@ poliwangi.ac.id
}

Diterima : Juli 2019

Disetujui : September 2019

\begin{abstract}
Prediction of agricultural products is needed in terms of planning and decision making as well as in policy making for national food security. One strategic commodity that needs special attention is rice. This study aims to predict rice yields using unmanned aircraft. The results of image acquisition are processed by multi thresholding method to separate leaf objects, rice panicles, and background. Furthermore, the results of sorting objects are used as input in making predictions of rice crop models using artificial neural networks. To compare the results of predictions, we weighed the weight of rice harvest on each block. The results showed that between predictions and actual correlations were very strong with $R^{2}=0.88, M S E$ (Mean Square Error) $=0.169$ and MAPE (Mean Absolute Percentage Error) values were -0.006. These results indicate that the prediction model of rice yields can be used for estimation purposes.
\end{abstract}

Keywords: artificial neural networks, rice, unmanned aircraft, prediction

\begin{abstract}
ABSTRAK
Prediksi hasil pertanian sangat dibutuhkan dalam hal perencanaan dan pengambilan keputusan serta dalam pengambilan kebijakan untuk ketahan pangan nasional. Salah satu komoditas strategis yang membutuhkan perhatian khusus adalah padi. Penelitian ini bertujuan untuk memprediksi hasil panen padi dengan menggunakan pesawat tanpa awak. Hasil akuisisi citra diolah dengan metode multi thresholding untuk memisahkan objek daun, malai padi, dan background. Selanjutnya hasil pemilahan objek dijadikan input dalam pembuatan model prediksi hasil panen padi dengan mengunakan jaringan syaraf tiruan. Penimbangan berat panen padi pada tiap blok dilakukan untuk membandingkan hasil prediksi. Hasil penelitian menunjukkan bahwa antara prediksi dan aktual memiliki korelasi sangat kuat dengan $\mathrm{R}^{2}=0,88$, nilai Mean Square Error $(\mathrm{MSE})=0,169$ dan Mean Absolute Percentage Error (MAPE) adalah -0,006. Hasil ini menunjukkan bahwa model prediksi hasil panen padi dapat digunakan untuk keperluan perkiraan.
\end{abstract}


Kata kunci: jaringan syaraf tiruan, padi, prediksi, pesawat tanpa awak

\section{Latar Belakang}

Prediksi hasil pertanian sangat dibutuhkan dalam hal perencanaan dan pengambilan keputusan serta dalam pengambilan kebijakan untuk ketahan pangan nasional. Hasil pertanian juga dikatakan sebagai indikator ketahanan pangan nasional, disamping juga sebagai elemen kunci untuk pembangunan pedesaan. Pada wilayah yang sangat luas, prediksi yang akurat, obyektif, handal, dan tepat waktu penting untuk ketahanan pangan nasional melalui pembuatan kebijakan (Li, $d k k$, , 2007).

Pada dekade terakhir mulai dikembangkan pertanian presisi (prescision agriculture). Pertanian presisi adalah paradigma pertanian yang memberikan perlakuan presisi dalam semua simpul-simpul rantai agribisnis (Seminar, 2011). Pada pertanian presisi, pemilihan lahan pertanian dapat dipilih dengan berdasarkan potensi dan kesesuian lahannya dengan menggunakan teknologi penginderaan jauh (inderaja) dan sistem informasi geografis (SIG). Teknologi penginderaan jauh mampu memberikan solusi dan kemudahan dalam analisis spasial secara berulang, continue, serta meliputi wilayah yang relatif luas (Sari dan Sukojo, 2015).

Penelitian prediksi hasil panen padi telah banyak dilakukan terutama yang menggunakan citra satelit, baik dari citra modis maupun citra landsat (Johnson $d k k$., 2016). Produktivitas hasil tanaman padi sawah berbasis kalender tanam heterogen dengan menggunakan kombinasi data citra satelit dengan data cuaca hasil pengamatan lapangan diestimasi oleh Sudarsono, dkk., (2016). Metode ini berbasis sintesis antara model produktivitas hasil tanaman dengan model deteksi fenologi padi sawah. Proses perbandingan antara Logika Fuzzy dengan modifikasi Logika Fuzzy untuk klasifikasi sembilan fase pertumbuhan padi berdasarkan citra hiperspektral dilakukan oleh Maspiyanti, dkk., (2016). Modifikasi Logika Fuzzy mampu meningkatkan akurasi hingga $10 \%$ jika dibandingkan dengan Logika Fuzzy.

Sementara itu, Astika, dkk., (2011) mengembangkan model estimasi hasil padi dengan menggunakan data MODIS dan menerapkan model ini ke daerah studi di wilayah Liling, China. Hasilnya menunjukkan korelasi yang signifikan $(\mathrm{p}<0,001)$ diamati di antara mereka, dan perkiraan 8-hari NPP lebih besar dari produk MODIS NPP. Akurasi model fase pertumbuhan padi berbasis MODIS diuji oleh Parsa, dkkl., (2017) di pulau Lombok terhadap citra Landsat multiwaktu dan data lapangan. Hasil analisis konsistensi model menunjukkan bahwa fase yang dihasilkan dari citra MODIS yang di-smoothing menunjukkan pola yang konsisten sebagaimana pola EVI tanaman padi dengan akurasi $86 \%$, sedangkan pola EVI citra MODIS yang tidak di-smoothing tidak konsisten.

Meskipun prediksi hasil panen padi telah banyak dilakukan menggunakan citra satelit, tetapi citra satelit sendiri masih terdapat banyak kelemahan. Citra yang dihasilkan oleh satelit adalah data lampau sehingga keakuratan data prediksi kurang maksimal. Citra satelit lebih banyak tertutup oleh awan, dan resolusi spasial yang digunakan cenderung rendah. Sehingga hal ini sangat mempengaruhi keandalan data. Beberapa tahun terakhir telah berkembang teknologi pesawat tanpa awak yang digunakan dalam beberapa bidang, salah satunya adalah bidang pertanian.

\section{Tujuan}

Penelitian ini bertujuan untuk memprediksi hasil panen padi menggunakan pesawat tanpa awak dengan pemotretan majemuk. diharapkan prediksi panen yang dihasilkan akan lebih akurat dan lebih handal. 


\section{METODE PENELITIAN}

\section{Lokasi}

Lokasi penelitian berada pada lahan pertanian Desa Watukebo, Kecamatan Blimbingsari, Kabupaten Banyuwangi atau terletak pada koordinat $8^{\circ} 17^{\prime} 37^{\prime \prime} \mathrm{S}$ dan $114^{\circ} 18^{\prime} 19^{\prime \prime}$ E dengan luas lahan 200 $\mathrm{m}^{2}$.

\section{Alat dan bahan}

Alat yang digunakan dalam penelitian ini adalah drone DJI phantom 4, tali, timbangan, rol meter, dan smartphone. Sedangkan bahan yang digunakan adalah aplikasi DJI, aplikasi drone deploy, dan matlab. Jenis padi yang diamati adalah jenis padi Inpari 32. Jarak tanam yang digunakan adalah jarak antar baris $15 \mathrm{~cm}$ dan jarak antar tanaman $25 \mathrm{~cm}$.

\section{Persiapan drone}

Pesawat tanpa awak (drone) yang digunakan dalam penelitian ini adalah drone keluaran DJI dengan jenis quadcopter. Aplikasi DJI dan aplikasi drone deploy diunduh melalui Appstore atau Play store. Kemudian dilakukan registrasi user. Selanjutnya meregistrasi wilayah terbang. Registrasi ini dapat dilakukan melalui web www.dronedeploy.com atau langsung dalam aplikasi drone deploy di smartphone. Dalam registrasi wilayah ditentukan tinggi terbang, overlap, arah pengambilan foto dan luasan areal pemotretan.

Dalam persiapan terbang beberapa hal yang harus diperhatikan adalah memastikan bahwa firmware pada aplikasi DJI adalah firmware yang terbaru dan kartu mikro SD dengan kapasitas yang cukup. Setelah set up sudah dilaksanakan maka peta dari gambar yang telah diambil siap untuk degenerate pada dekstop computer

\section{Akuisisi Citra}

Akuisisi citra dilakukan pada saat menjelang panen. Petakan sawah dibuat ubinan dengan ukuran 2,5 x 2,5 m menggunakan tali. Pesawat drone diterbangkan dengan ketinggian $4 \mathrm{~m}$ pada setiap ubinan untuk mejaga posisi padi agar tidak terkena tiupan angin dari baling baling drone yang menjadikan citra buram akibat pergerakan tanaman.

\section{Pengolahan Citra}

Pengolahan citra dilakukan dengan menggunakan metode multi tresholding. Metode ini difungsikan untuk memisahkan suatu citra dalam beberapa region berdasarkan dari nilai intensitas piksel yang sebelumnya sudah diubah dalam bentuk greyscale. Pada prinsipnya, metode multi-thresholding sama seperti metode thresholding, yaitu segmentasi citra didasarkan pada perbedaan derajat keabuan. Perbedaannya adalah pada jumlah nilai threshold yang digunakan. Pada penelitian ini, menggunakan 3 segmentasi untuk membedakan malai padi, daun, dan objek background. Hasil segmentasi dihitung berdasarkan persentase pada segmentasi piksel. Hasil panen diprediksi dengan menggunakan Jaringan Syaraf Tiruan (JST). Peramalan JST termasuk ke dalam peramalan objektif karena didasarkan atas data yang relevan pada masa lalu dengan menggunakan teknik-teknik dan metode-metode dalam penganalisaan data tersebut (Fadila, 2009).

Arsitektur jaringan syaraf tiruan yang dibentuk menggunakan 3 neuron input meliputi data persentase piksel pada region 1 (X1), region 2 (X2), dan region 3 (X3), 2 hidden layer dan 1 neuron output sebagai target data yaitu berat padi (Y). sedangkan fungsi aktivasi yang digunakan adalah Backpropagation.

\section{Penimbangan Gabah}

Penimbangan gabah dilakukan setelah semua pengamatan secara visual telah selesai dilakukan. Penimbangan gabah ini dilakukan untuk megetahui hasil panen padi secara nyata dalam setiap grid. 


\section{HASIL DAN PEMBAHASAN}

\section{Hasil akuisisi citra}

Citra yang dihasilkan dalam penelitian ini dikelompokkan ke dalam blokblok untuk memudahkan dalam pengolahan citra. Blok diberi label dari blok A1 sampai dengan blok $\mathrm{H} 4$, sehingga total ada 32 data hasil dari akuisisi citra. Proses pelabelan blok dapat dilihat pada Gambar 1. Dalam pembuatan ubinan, dilakukan dengan membentangkan tali pada petak sawah, kemudian diposisikan bahwa panjang dan lebar ubinan adalah 2,5 x 2,5 m.
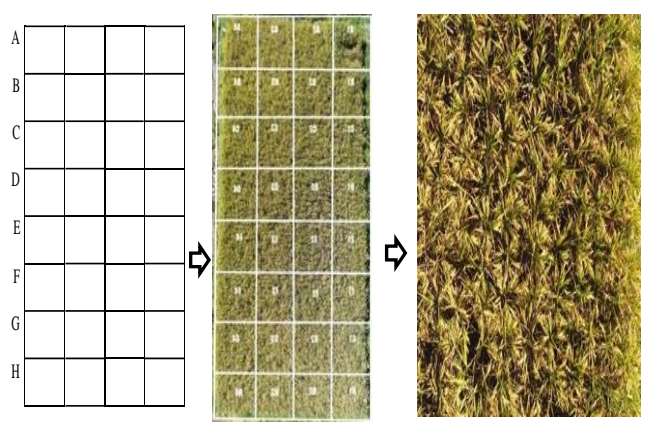

Gambar 1. Proses akuisisi citra dengan ubinan blok

\section{Hasil pengolahan citra}

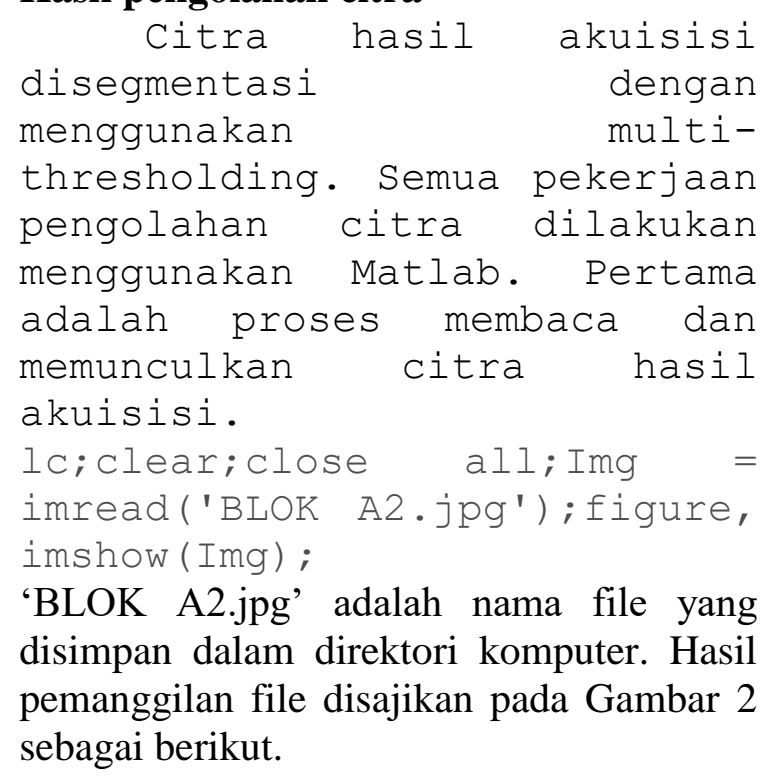

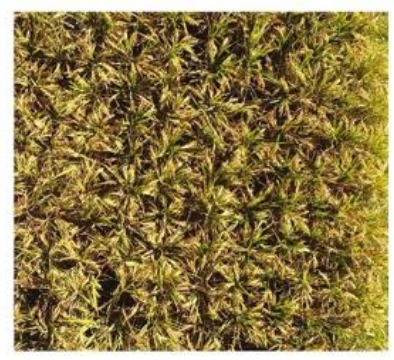

Gambar 2. Memunculkan Citra Asli

Selanjutnya citra diubah dalam bentuk greyscale dengan mengekstrak komponen warna kuning dari citra asli, seperti pada Gambar 3. Hal ini bertujuan untuk menyederhanakan objek citra.
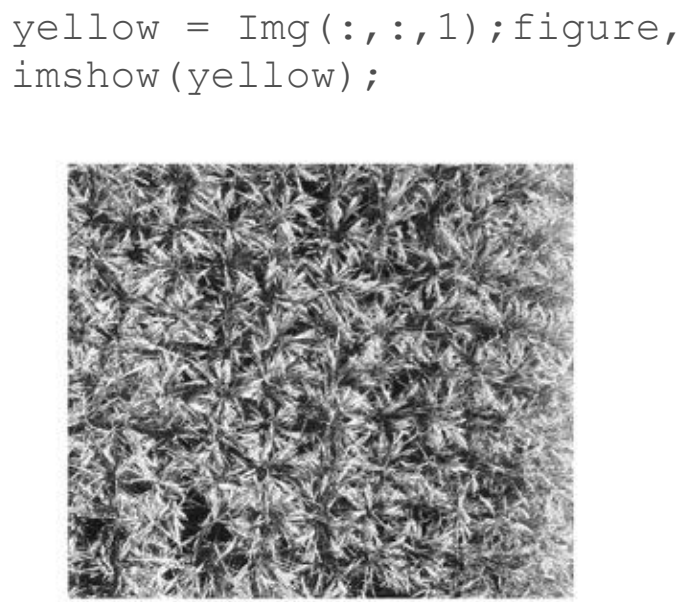

Gambar 3. Hasil citra akusisi dalam bentuk greyscale

Tahap berikutnya dilakukan proses multi-thresholding dengan nilai threshold pada rentang 100 dan 230. Nilai intensitas piksel antara 0-100 masuk kedalam region 1 . Nilai intensitas piksel antara 100-230 masuk kedalam region 2. Dan nilai intensitas piksel antara 230-255 masuk kedalam region 3.

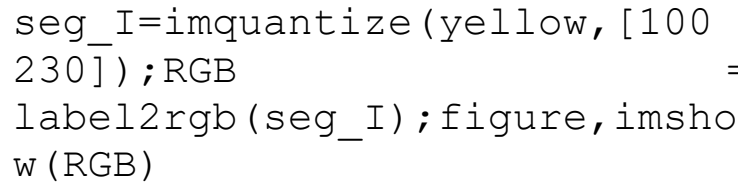

region 1 ditampilkan oleh objek berwarna biru, region 2 berwarna cyan, dan region 3 berwarna kuning disajikan pada Gambar 4. 


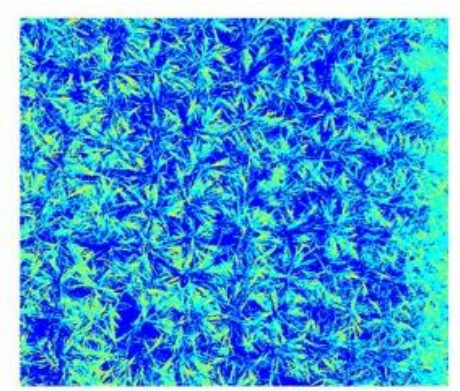

Gambar 4. Hasil multi-Thresholding

Selanjutnya ditampilkan hasil segmentasi dari masing-masing region dengan kode sebagai berikut;

segmented images $=$

cell $(1,3)$; rgb_label =

repmat (seg_I, $\left.\left[\begin{array}{lll}1 & 1 & 3\end{array}\right]\right)$;

nRegions $=3$; color (rgb_label

$\sim=\mathrm{k})=0$;

segmented_images $\{\mathrm{k}\}=$

color;for $\mathrm{k}=1$ :nRegions

color $=$

Img; figure, imshow (segmented_im ages $\{\mathrm{k}\})$,

title(strcat(['objects in

region ', num2str(k)])) ; end

Hasil pemisahan region ditampilkan pada Gambar 5, dimana region 1 adalah citra background, region 2 adalah citra daun, dan region 3 adalah citra malai padi. Tiap-tiap region dihitung jumlah pikselnya, hal ini tersaji pada Tabel 1.
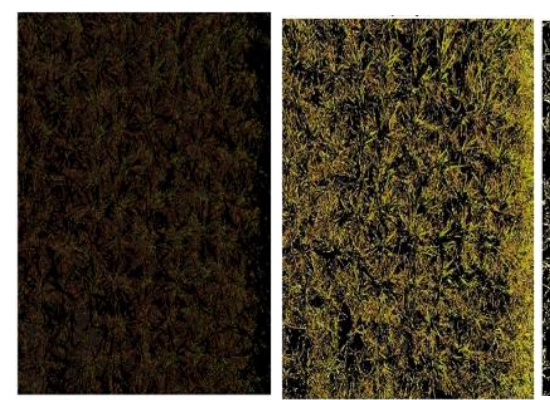

Regio

n 1

Regio

n?

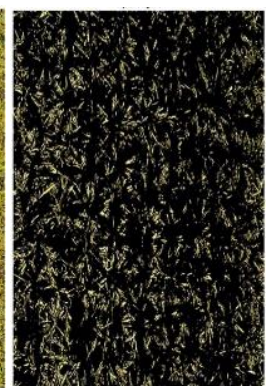

Regio

Gambar 5. Hasil segmentasi citra
Tabel 1. Data persentase piksel tiap region

\begin{tabular}{|c|c|c|c|}
\hline Blok & $\begin{array}{c}\text { Persentase } \\
\text { Region } 1 \\
\text { (objek } \\
\text { background) }\end{array}$ & $\begin{array}{c}\text { Persentase } \\
\text { Region } 2 \\
\text { (objek } \\
\text { daun) } \\
\end{array}$ & $\begin{array}{c}\text { Persentase } \\
\text { Region } 3 \\
\text { (objek } \\
\text { malai) } \\
\end{array}$ \\
\hline A1 & $45 \%$ & $45 \%$ & $10 \%$ \\
\hline $\mathrm{A} 2$ & $37 \%$ & $49 \%$ & $14 \%$ \\
\hline A3 & $45 \%$ & $45 \%$ & $10 \%$ \\
\hline A4 & $41 \%$ & $49 \%$ & $10 \%$ \\
\hline B1 & $46 \%$ & $45 \%$ & $9 \%$ \\
\hline B2 & $46 \%$ & $46 \%$ & $8 \%$ \\
\hline B3 & $47 \%$ & $41 \%$ & $12 \%$ \\
\hline B4 & $47 \%$ & $41 \%$ & $12 \%$ \\
\hline $\mathrm{C} 1$ & $47 \%$ & $40 \%$ & $13 \%$ \\
\hline $\mathrm{C} 2$ & $34 \%$ & $59 \%$ & $7 \%$ \\
\hline C3 & $31 \%$ & $64 \%$ & $5 \%$ \\
\hline $\mathrm{C} 4$ & $24 \%$ & $71 \%$ & $5 \%$ \\
\hline D1 & $32 \%$ & $51 \%$ & $18 \%$ \\
\hline D2 & $38 \%$ & $54 \%$ & $8 \%$ \\
\hline D3 & $35 \%$ & $58 \%$ & $7 \%$ \\
\hline D4 & $25 \%$ & $70 \%$ & $5 \%$ \\
\hline E1 & $31 \%$ & $61 \%$ & $7 \%$ \\
\hline E2 & $49 \%$ & $46 \%$ & $5 \%$ \\
\hline E3 & $50 \%$ & $45 \%$ & $5 \%$ \\
\hline E4 & $36 \%$ & $61 \%$ & $2 \%$ \\
\hline $\mathrm{F} 1$ & $25 \%$ & $62 \%$ & $14 \%$ \\
\hline $\mathrm{F} 2$ & $41 \%$ & $50 \%$ & $9 \%$ \\
\hline F3 & $41 \%$ & $50 \%$ & $9 \%$ \\
\hline F4 & $47 \%$ & $48 \%$ & $5 \%$ \\
\hline G1 & $36 \%$ & $62 \%$ & $2 \%$ \\
\hline G2 & $31 \%$ & $66 \%$ & $3 \%$ \\
\hline G3 & $32 \%$ & $63 \%$ & $4 \%$ \\
\hline G4 & $40 \%$ & $47 \%$ & $13 \%$ \\
\hline H1 & $28 \%$ & $51 \%$ & $21 \%$ \\
\hline $\mathrm{H} 2$ & $43 \%$ & $44 \%$ & $13 \%$ \\
\hline H3 & $14 \%$ & $76 \%$ & $9 \%$ \\
\hline $\mathrm{H} 4$ & $17 \%$ & $79 \%$ & $5 \%$ \\
\hline
\end{tabular}

Tabel 1 menunjukkan data persentase piksel tiap region. Region 1 menunjukkan data piksel untuk objek background, region 2 menunjukkan data piksel untuk objek daun, sedangkan region 3 menunjukkan data piksel objek malai padi. Data piksel objek background dan objek daun menunjukkan nilai persentase yang lebih tinggi dibandingkan dengan data piksel objek malai padi. Hal ini dikarenakan kuantitas malai 
lebih rendah apabila dibandingkan dengan daun dan background

\section{Hasil Penimbangan}

Blok disusun 4 kolom (1-4) dan 8 baris (A-H), sehingga total terdapat 32 blok.

Tabel 2. Data Hasil Penimbangan

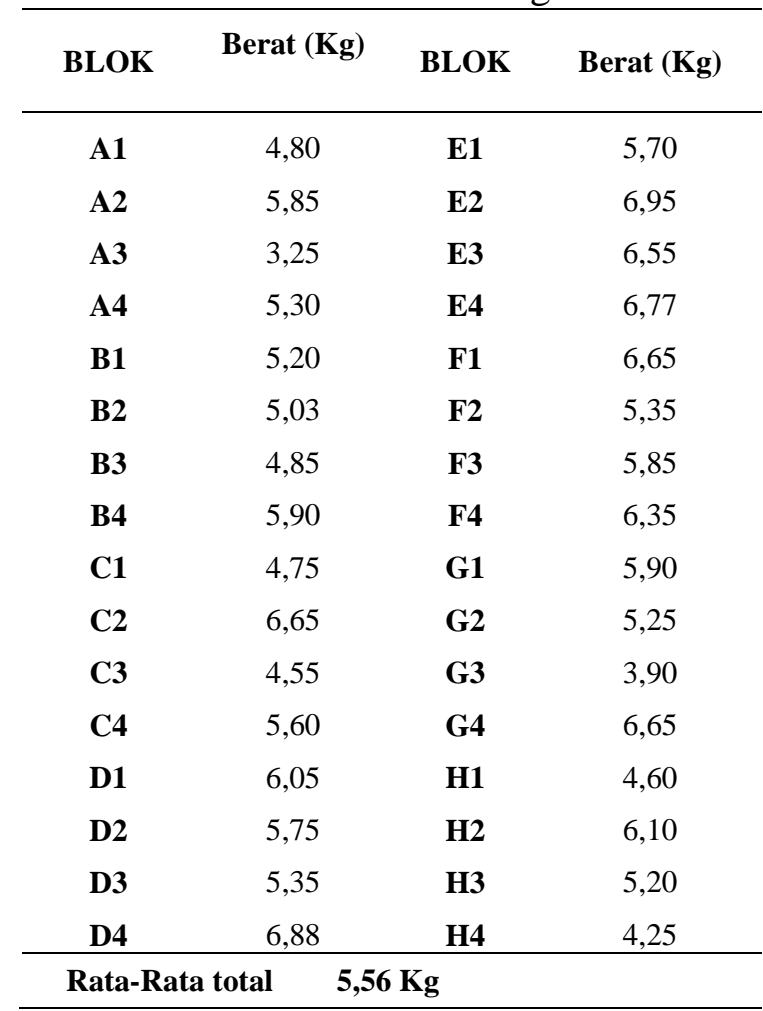

Tabel 2 menunjukkan berat-rata $5,56 \mathrm{Kg}$ atau memiliki produktivitas $0,89 \mathrm{~kg} / \mathrm{m}^{2}(8,9$ ton/ha). Hal ini menunjukkan bahwa padi yang ditanam memiliki produktivitas relatif tinggi dibandingkan hasil produksi pada umumnya

\section{Hasil Prediksi}

Prediksi hasil panen padi diolah dengan menggunakan jaringan syaraf tiruan (JST). Data total yang digunakan dalam pembentukan arsitektur jaringan syaraf tiruan sebanyak 32 data. 22 data atau $80 \%$ dari jumlah data digunakan sebagai data training. Proses validasi dan pengujian masing masing menggunakan 3 data atau $10 \%$ dari jumlah data. Input terdiri atas persentase piksel tiaptiap region dan output adalah berat padi tiap blok. Parameter arsitektur yang dibuat menggunakan 1000 epoch dengan learning rate 0,01 . Nilai epoch yang digunakan relatif lebih sedikit dibandingkan dengan (Romadhona, $d k k ., 2018$ ) yang menggunakan epoch sampai dengan 10000 bahkan (Adrijasa dan Mistianingsih, 2010) mempergunakan epoch sampai dengan 500000. Nilai epoch yang tinggi akan menjadikan proses iterasi akan berjalan lama. Jumlah neuron hidden layer dilakukan secara trial and error dan sangat menentukan hasil dari pembelajaran (Romadhona, et al., 2018). Hasil pembentukan arsitektur jaringan syaraf tiruan yang dipilih dalam penelitian ini adalah 12 neuron hidden layer. Hal ini didasarkan pada nilai MSE terkecil dan $\mathrm{R}^{2}$ terbesar (Tabel 3). Sehingga arsitektur jaringan syaraf tiruan yang dibentuk adalah 3-12-1.

Tabel 3. Arsitektur jaringan syaraf tiruan (JST)

\begin{tabular}{cccc}
\hline $\begin{array}{c}\text { Jumlah } \\
\text { Hidden } \\
\text { Neurons }\end{array}$ & $\begin{array}{c}\text { Algoritma } \\
\text { pelatihan }\end{array}$ & MSE & $\mathbf{R}^{\mathbf{2}}$ \\
\hline 4 & Trainlm & 0,425 & 0,694 \\
6 & Trainlm & 0,419 & 0,702 \\
8 & Trainlm & 0,244 & 0,834 \\
10 & Trainlm & 0,332 & 0,797 \\
12 & Trainlm & 0,169 & 0,888 \\
14 & Trainlm & 0,383 & 0,729 \\
16 & Trainlm & 0,366 & 0,770 \\
\hline
\end{tabular}

Hasil perbandingan antara berat aktual dan berat prediksi dibandingkan untuk melihat kehandalan data hasil prediksi. Secara keseluruhan data hasil prediksi (Tabel 4) memiliki nilai yang mendekati nilai aktual. Hanya beberapa data yaitu pada blok A3, B1, B4, dan F4 yang memiliki persentase error lebih dari $10 \%$. 
Tabel 4. Hasil Prediksi Berat Padi menggunakan Metode JST

\begin{tabular}{|c|c|c|c|c|c|}
\hline . Blok & $\begin{array}{c}\text { Berat } \\
\text { aktual } \\
(\mathbf{K g})\end{array}$ & $\begin{array}{c}\text { Berat } \\
\text { prediksi } \\
\text { JST (Kg) }\end{array}$ & error & $\begin{array}{c}\text { kuadr } \\
\text { at } \\
\text { error }\end{array}$ & $\begin{array}{c}\text { persenta } \\
\text { se error }\end{array}$ \\
\hline $\mathrm{A} 1$ & 4,80 & 4,568 & 0,232 & 0,054 & $4,83 \%$ \\
\hline A2 & 5,85 & 5,854 & $-0,004$ & 0,000 & $-0,06 \%$ \\
\hline A3 & 3,25 & 4,568 & $-1,318$ & 1,738 & $-40,56 \%$ \\
\hline A4 & 5,30 & 5,159 & 0,141 & 0,020 & $2,66 \%$ \\
\hline B1 & 5,20 & 4,662 & 0,538 & 0,290 & $10,36 \%$ \\
\hline B2 & 5,03 & 5,172 & $-0,142$ & 0,020 & $-2,83 \%$ \\
\hline B3 & 4,85 & 5,082 & $-0,232$ & 0,054 & $-4,79 \%$ \\
\hline B4 & 5,90 & 5,082 & 0,818 & 0,668 & $13,86 \%$ \\
\hline $\mathrm{Cl}$ & 4,75 & 5,142 & $-0,392$ & 0,153 & $-8,24 \%$ \\
\hline $\mathrm{C} 2$ & 6,65 & 6,146 & 0,504 & 0,254 & $7,58 \%$ \\
\hline C3 & 4,55 & 4,697 & $-0,147$ & 0,022 & $-3,24 \%$ \\
\hline $\mathrm{C} 4$ & 5,60 & 5,935 & $-0,335$ & 0,112 & $-5,98 \%$ \\
\hline D1 & 6,05 & 6,024 & 0,026 & 0,001 & $0,43 \%$ \\
\hline D2 & 5,75 & 5,721 & 0,029 & 0,001 & $0,50 \%$ \\
\hline D3 & 5,35 & 5,880 & $-0,530$ & 0,281 & $-9,91 \%$ \\
\hline D4 & 6,88 & 6,516 & 0,364 & 0,132 & $5,29 \%$ \\
\hline E1 & 5,70 & 5,715 & $-0,015$ & 0,000 & $-0,27 \%$ \\
\hline E2 & 6,95 & 6,837 & 0,113 & 0,013 & $1,63 \%$ \\
\hline E3 & 6,55 & 6,719 & $-0,169$ & 0,029 & $-2,58 \%$ \\
\hline E4 & 6,77 & 6,575 & 0,195 & 0,038 & $2,88 \%$ \\
\hline F1 & 6,65 & 6,613 & 0,037 & 0,001 & $0,55 \%$ \\
\hline $\mathrm{F} 2$ & 5,35 & 5,309 & 0,041 & 0,002 & $0,77 \%$ \\
\hline F3 & 5,85 & 5,309 & 0,541 & 0,293 & $9,25 \%$ \\
\hline $\mathrm{F} 4$ & 6,35 & 7,253 & $-0,903$ & 0,816 & $-14,22 \%$ \\
\hline G1 & 5,90 & 5,997 & $-0,097$ & 0,009 & $-1,64 \%$ \\
\hline G2 & 5,25 & 5,132 & 0,118 & 0,014 & $2,24 \%$ \\
\hline G3 & 3,90 & 4,040 & $-0,140$ & 0,020 & $-3,60 \%$ \\
\hline G4 & 6,65 & 6,139 & 0,511 & 0,261 & $7,68 \%$ \\
\hline $\mathrm{HI}$ & 4,60 & 4,607 & $-0,007$ & 0,000 & $-0,16 \%$ \\
\hline $\mathrm{H} 2$ & 6,10 & 5,763 & 0,337 & 0,114 & $5,53 \%$ \\
\hline $\mathrm{H} 3$ & 5,20 & 5,179 & 0,021 & 0,000 & $0,41 \%$ \\
\hline $\mathrm{H} 4$ & 4,25 & 4,208 & 0,042 & 0,002 & $1,00 \%$ \\
\hline \multicolumn{4}{|c|}{ Mean Squared Error (MSE) } & 0.169 & \\
\hline \multicolumn{5}{|c|}{ Mean Absolute Percentage Error (MAPE) } & -0.006 \\
\hline
\end{tabular}

Tabel 4 menunjukkan data hasil peramalan, perhitungan error, perhitungan Mean Square Error (MSE) dan Mean Absolute Percentage Error (MAPE). Nilai MSE digunakan untuk mengukur seberapa baik taksiran parameter yang diperoleh. Nilai MSE menunjukkan nilai 0,169 . Hal ini menunjukkan bahwa nilai rata-rata error yang dimiliki oleh model ini adalah 16,9\%. Nilai MSE ini lebih rendah dari penelitian (Revi et al, 2018) dan lebih tinggi dari (Meychael et al., 2018). Nilai MAPE menunjukkan nilai -0,006, hal ini menunjukkan nilai keragaman dari galat/error dari model peramalan yang relatif kecil. Tanda negatif menjelaskan bahwa nilai berat aktual lebih kecil dibandingkan dengan nilai berat hasil prediksi. Nilai MAPE yang dihasilkan lebih baik dari (Febrina $d k k$., 2013) yang sama-sama menggunakan JST untuk prediksi. Nilai MSE dan MAPE yang dihasilkan telah cukup baik untuk proses perkiraan. Hubungan dan pola antara berat aktual dan berat prediksi dapat dilihat pada Gambar 6.

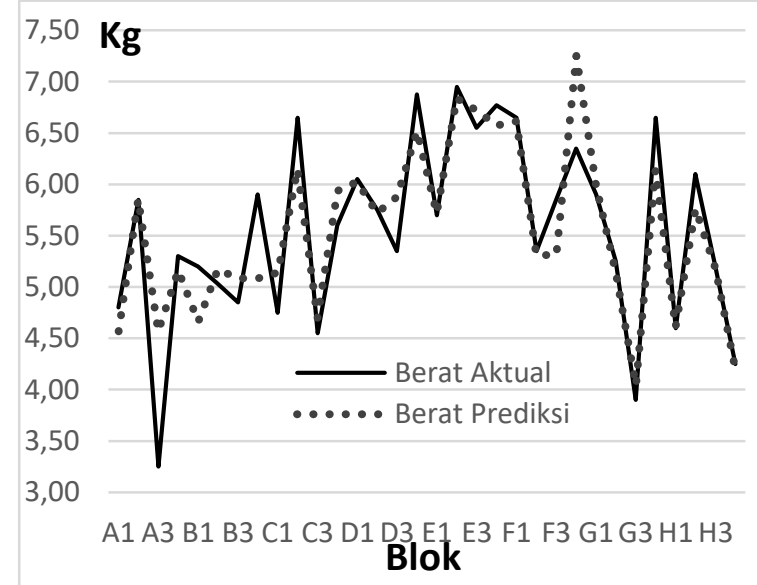

Gambar 6. Perbedaan berat aktual dengan berat hasil prediksi

Gambar 6 menunjukkan perbedaan antara berat aktual dengan berat hasil peramalan. Tren berat aktual dan berat hasil peramalan menunjukkan pola yang serupa, namun masih terdapat perbedaan (gap) antara nilai berat aktual dengan nilai berat peramalan. Perbedaan yang ditunjukkan tidak terlalu besar, sehingga data hasil peramalan dapat digunakan untuk memprediksi dengan baik. Tingkat hubungan antara berat aktual dan berat prediksi terlihat pada Gambar 7 . 


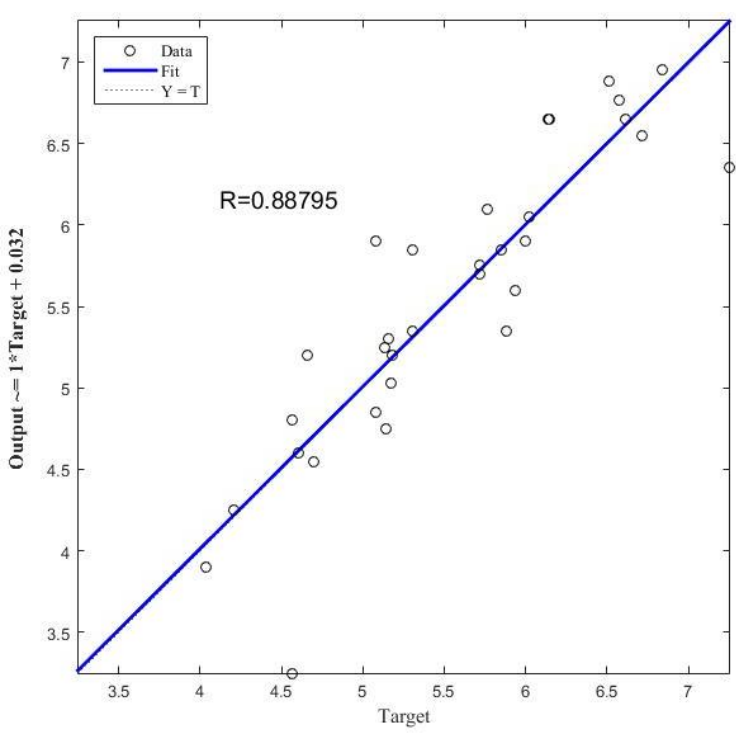

Gambar 7. Hasil korelasi berat aktual dan berat prediksi

Gambar 7 menunjukkan bahwa hasil $\mathrm{R}$ korelasi adalah 0,888 . Nilai ini menunjukkan bahwa tingkat hubungan / korelasi antara berat padi aktual dan berat padi hasil prediksi sebesar $88,8 \%$. Keterkaitan yang sangat erat ini menunjukkan bahwa data berat padi hasil prediksi tidak berbeda jauh dengan berat padi aktual, sehingga model prediksi ini dapat dimanfaatkan oleh petani. Petani dapat menentukan keputusan mengenai kegiatan budidaya padi setelah mengetahui hasil prediksi berat padi. Apabila hasil peramalan berat padi rendah, petani dapat melakukan beberapa kegiatan budidaya yang dapat meningkatkan berat padi, dengan pemberian pupuk secara optimal, dan perawatan tanaman padi dari hama dan penyakit.

\section{KESIMPULAN}

Berdasarkan dari penelitian yang telah dilakukan terhadap prediksi hasil panen padi menggunakan pesawat tanpa awak, maka dapat disimpulkan bahwa citra hasil akusisi dapat dipisahkan antara objek background, objek daun, dan objek malai. Sehingga dapat dilakukan penaksiran hasil panen padi, tetapi objek daun masih banyak terikut dalam citra padi. Hal ini dikarenakan warna objek daun yang hampir sama dengan objek malai padi. Hasil pengujian korelasi menunjukkan nilai 0,888 atau $88,8 \%$. Nilai ini menunjukkan bahwa tingkat hubungan/korelasi antara berat padi aktual dan berat padi hasil prediksi tidak berbeda jauh, sehingga hasil pemodelan dapat digunakan untuk kepentingan penaksiran.

\section{UCAPAN TERIMA KASIH}

Peneliti mengucapkan terima kasih kepada Direktorat Riset dan Pengabdian Masyarakat Kementerian Riset, Teknologi, dan Pendidikan Tinggi atas dukungan yang diberikan kepada peneliti berupa bantuan dana penelitian yang menunjang berlangsungnya penelitian ini dengan baik. Ucapan terima kasih juga kami sampaikan ke Politeknik Negeri Banyuwangi telah memberikan dukungan yang menunjang berlangsungnya penelitian.

\section{DAFTAR ISI}

Andrijasa, M.F., Mistianingsih. (2010) Penerapan Jaringan Syaraf Tiruan untuk Memprediksi Jumlah Pengangguran di Provinsi Kalimantan Timur Dengan Menggunakan Algoritma Pembelajaran Backpropagation. Jurnal Informatika Mulawarma. Vol.1 (10) : 50-54

Astika, I. W., Suud, H. M., Setiawan, R. P. A., Faiz Syuaib, M., \& Solahudin, M. (2011). Pendugaan Produktivitas Padi Dengan Pengolahan Citra Yang Diambil Dari Pesawat Terbang Mini. In Seminar Nasional Perteta (pp. 106-112). Bandung. https://doi.org/10.14358/PERS.73.10.11 49

Fadila, A.A. (2019). Aplikasi Jaringan Syaraf Tiruan dalam Memprediksi Penjualan Mobil pada PT.Hadji Kalla Sengkang. [Skripsi]. Universitas Islam Negeri Makassar.

Febrina, M. Arina, F, Ekawati,R.(2013). Peramalan Jumlah Permintaan Produksi Menggunakan Metode Jaringan Syaraf Tiruan (JST) Backpropagation. Jurnal Teknik Industri,Juni 2013. Vol.1 (2) :174-179

Hutabarat, M.A.P Julham, M., Wanto, A. (2018) Penerapan Algoritma 
Backpropagation Dalam Memprediksi Produksi Tanaman Padi Sawah Menurut Kabupaten/Kota Di Sumatera Utara. semanTIK. Vol.4(1) : 77-86

Johnson, M. D., Hsieh, W. W., Cannon, A. J., Davidson, A., \& Bédard, F. (2016). Crop yield forecasting on the Canadian Prairies by remotely sensed vegetation indices and machine learning methods. Agricultural and Forest Meteorology, 218-219, 74-84. https://doi.org/10.1016/j.agrformet.2015 .11 .003

Li, A., Liang, S., Wang, A., \& Qin, J. (2007). Estimating Crop Yield from Multitemporal Satellite Data Using Multivariate Regression and Neural Network Techniques. Photogrammetric Engineering \& Remote Sensing, 73(10), 1149-1157.

Parsa,M I., Dirgahayu, D., \& Manalu, J. (2017). Uji Model Fase Pertumbuhan Padi Berbasis Citra Modis Multiwaktu Di Pulau Lombok (the Testing of Phase Growth Rice Model Based on Multitemporal Modis in Lombok Island). Jurnal Penginderaan Jauh. Vol. 14(1 : 51-64.

Maspiyanti, F., Fanany, M. I., \& Arymurthy, A. M. (2013). Klasifikasi Fase Pertumbuhan Padi Berdasarkan Citra Hiperspektral dengan Modifikasi Logika Fuzzy ( Paddy Growth Stages Classification based on Hyperspectral Image using Modified Fuzzy Logic). Jurnal Penginderaan Jauh, Vol 10(1), 41-

48.https://doi.org/10.5281/zenodo.3416 4
Ramadhona, G, Setiawan, B. D., Bachtiar, F., A. (2018) Prediksi Produktivitas Padi Menggunakan Jaringan Syaraf Tiruan Backpropagation Jurnal Pengembangan Teknologi Informasi dan Ilmu Komputer. Vol. 2 (12) : 60486057

Revi, A., Parlina, I. M. Safii, M. (2018). Model Jaringan Syaraf Tiruan Memprediksi Produksi Padi Indonesia Berdasarkan Provinsi. Jurnal Teknovasi. Vol 05 (2): 1-13

Sari, V. D., \& Sukojo, B. M. (2015). Analisa Estimasi Produksi Padi Berdasarkan Fase Tumbuh Dan Model Peramalan Autoregressive Integrated Moving Average (Arima) Menggunakan Citra Satelit Landsat 8 (Studi Kasus: Kabupaten Bojonegoro) Vivi. GEOID, Vol 10(2):194-2013.

Seminar, K. B. (2011). Paradigma Pendayagunaan Teknologi Informasi Untuk Pertanian. In Seminar Nasional Informatika Pertanian (pp. 1-9).

Sudarsono, N. W., Sudarsono, B., \& Wijaya, A. P. (2016). Analisis Fase Tumbuh Padi Menggunakan Algoritma Ndvi, Evi, Savi, Dan Lswi Pada Citra Landsat 8. Jurnal Geodesi Undip, 5(1), 125-134. 